\title{
Mitigation of alkali-silica reaction in US highway concrete
}

\section{Kevin J. Folliard}

Professor and Austin Industries Teaching Fellow, Department of Civil, Architectural, and Environmental Engineering, The University of Texas at Austin, Austin, TX, USA (corresponding author: folliard@mail.utexas.eud) Michael D. A. Thomas

Professor, University of New Brunswick, New Brunswick, Canada

Benoit Fournier

Professor, Universite de Sherbrooke, Quebec City, Canada

\section{Thano Drimalas}

Research Associate, The University of Texas at Austin, Austin, TX, USA Gina Ahlstrom

Pavement Design and Analysis Team Leader, Office of Asset Management, Pavements, and Construction (HIAP), Federal Highway Administration, Washington, DC, USA

This paper provides an overview of the various field trials performed by the US Federal Highway Administration aimed at mitigating the effects of alkali-silica reaction on highway concrete elements, including pavements, bridges and barriers. The different methods used to attempt to reduce the expansion and cracking of affected concrete are described, including the use of sealings and coatings, the application of lithium nitrate and the application of external confinement. The field trials were conducted and monitored between 2005 and 2014, and the overall findings from each trial are briefly summarised. The use of silane products was found to be the most effective means of reducing the expansion and cracking due to alkali-silica reaction, with the most significant improvement seen in highway barriers. Topical and vacuum application of lithium compounds showed little or no benefit in reducing expansion and cracking, mainly due to the lack of lithium penetration. Electrochemical application of lithium nitrate was more effective in driving the lithium into the affected concrete, but had a negligible impact on the expansion and cracking induced by alkali-silica reaction. Owing to the limited time that was available to monitor most of the field trials, future monitoring is essential to delineate the efficacy of the various treatments.

\section{Introduction}

Alkali-silica reaction (ASR) has been a significant cause of distress in concrete structures and pavements throughout the world, and the USA is no exception, with ASR-induced expansion reported in most, if not all 48 contiguous states. To address the concern over ASR in transportation infrastructure, the US Federal Highway Administration (FHWA) launched the ASR Development and Deployment Program, which included nine field trials conducted across the USA that evaluated the mitigation measures applied to concrete structures and pavements already exhibiting ASR-induced distress. The first treatment and monitoring of these structures and pavements began in 2005, but the majority of the field trials were initiated between 2009 and 2012. This paper provides a broad overview of this field testing programme; a more detailed summary of the nine field trials and the results of early monitoring are included in the final FHWA reports (Thomas et al., 2013a, 2013b).

\section{Field sites - selection, diagnosis and treatment}

Guidelines for diagnosing, prognosing and selecting the mitigation measures for ASR-affected structures, also developed under this FHWA project (Fournier et al., 2010), were followed in order to identify candidate structures and potential mitigation/repair options. In coordination with the various state departments of transportation (DOTs), field visits were initiated to perform an initial, visual survey of the structure(s) proposed for treatment. Based on these field observations, recommendations were then made for the extraction of cores from selected concrete members in order to perform petrographic examination and mechanical testing (when possible), to confirm the contribution of ASR to the deleterious process affecting the structure under investigation.

The diagnosis of ASR was then made in the laboratory through petrographic examination, specifically, the damage rating index (DRI), a method that provides a semi-quantitative assessment of the degree of damage in concrete based on a count of petrographic features of deterioration generally associated with ASR (Fournier et al., 2009). The DRI was found to be an effective tool throughout these field trials, as evidenced by the example shown in Figure 1. This figure shows the DRI results for three portions of a bridge structure in Maine that were subjected to different exposure conditions that resulted in significantly more expansion and cracking in the sections 


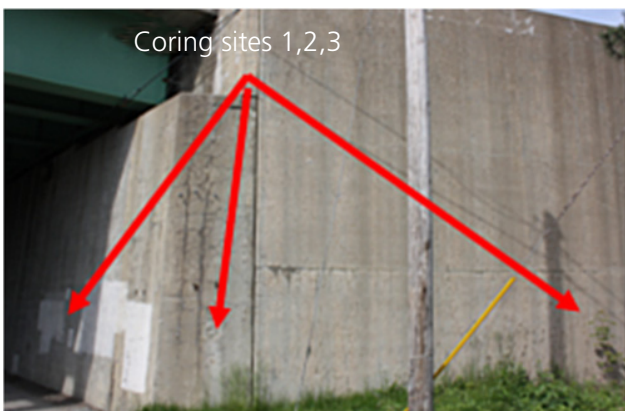

(a)

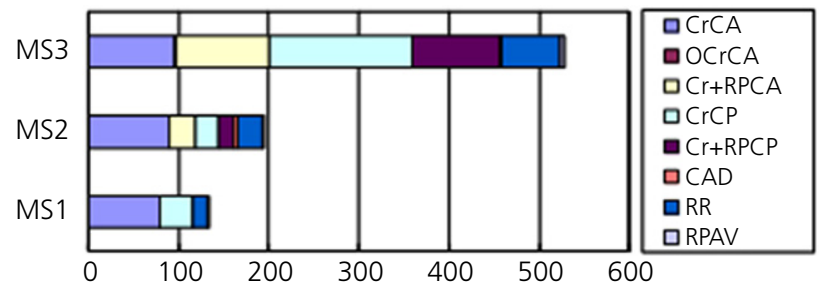

(b)

Figure 1. (a) Locations of cores extracted from bridge structure I-395 over Main Street in Bangor, Maine, USA. (b) Results of the DRI from extracted cores. MS1: abutment wall under the bridge deck, sheltered (no cracking); MS2: exposed portion of the abutment wall (map cracked); MS3: exposed portion of the wing wall (map cracked). The shaded cells give the proportions of each petrographic feature to the DRI value. CrCA: cracking in the coarse aggregate particles; $\mathrm{OCrCa}$ : opened cracking in the coarse aggregate particles; $\mathrm{Cr}+\mathrm{RPCA}$ : cracking in the coarse aggregate particles + reaction product; $C r C P$ : cracking in the cement paste; $\mathrm{Cr}+\mathrm{RPCP}$ : cracking in the cement paste + reaction product; CAD: coarse aggregate debonded; RR: reaction rim; RPAV: reaction products in air void of the cement paste

exposed most to external moisture (MS3) and the least for the section sheltered from moisture by the bridge structure (MS1). The petrographic evaluations, including the DRI results, for all of the field trials, are included in the final FHWA final report, volume II (Thomas et al., 2013b). In one case (structures in Maine), additional cores were extracted and tested using the stiffness damage test, a test that evaluates the degree/extent of damage in concrete through loading/unloading cycles in compression.

Table 1 describes the nine field trials performed under this FHWA project, including the date and location of the treatments, the type(s) of structures treated and the methods/ materials used. The trials were performed in eight different states (with two in Texas). The first trial was the treatment of highway barriers in Leominster, Massachusetts in 2005; additional treatments were performed in Leominster, and the overall test section was expanded in 2010. Trials were initiated as late as 2012 , with very little available time for monitoring before the completion of the FHWA project in 2013. There were two trials in Texas, one involving the treatment of various bridge columns in Houston and the other involving the evaluation of precast concrete girders. In the former trial in Texas, the bridge columns were initially treated in 2006, under a separate FHWA project that had already concluded. The FHWA deployment programme described in this paper restarted the monitoring efforts, thus allowing for long-term monitoring of this bridge structure in Houston. In the latter trial in Texas, it was determined that these specific girders were not suffering from ASR-induced expansion and cracking; nevertheless, these girders were treated with silanes and monitored under this field trial programme for completeness and to help to elucidate the cause of distress and whether reducing internal humidity might be effective in reducing surface cracking. Figure 2 shows selected photographs of some of the treatment methods used during these trials.

\section{Field sites - performance monitoring}

Following the confirmation of ASR as one of the main contributing factors to deterioration, a treatment scheme was developed and implemented which, depending on the type of structure, its detailing, and condition, included one or several of the following options: chemical treatment (lithium), topical treatment (sealers and/or breathable coating) and strengthening (fibre-reinforced polymer (FRP) wrap). A performancemonitoring plan was also developed and implemented to allow the quantification of the effects of the various treatments over time; it included regular (once or twice a year) monitoring of the expansion, surface cracking and relative humidity/ temperature in the treated and untreated (control) sections of the selected structures, as shown in Figure 3.

Table 2 summarises the main observations and trends observed through the completion of the project monitoring. Because most of the field trials were initiated towards the end of this project, only minimal monitoring time was possible for most of the structures and pavements treated under this project. As such, conclusions are not yet possible, nor are trends evident, for these structures. For the field trials with the longest monitoring periods, such as the highway barriers in Massachusetts and the bridge columns, some clearer trends have emerged, as described in the following.

Figure 4 shows the significant reduction in cracking imparted through the topical application of silane-based products to the highway barriers in Massachusetts. This visual improvement is supported by measured reductions in internal humidity (typically 10\% lower than for untreated barriers) and measured reductions in vertical expansion (Thomas et al., 2013b). 


\begin{tabular}{|c|c|c|c|}
\hline Field site (date treated) & Elements treated & & hnologies evaluated \\
\hline Alabama (2010) & $\begin{array}{l}\text { Concrete arches on a bridge } \\
\text { (above the roadway) }\end{array}$ & $\mathbf{\square}$ & $\begin{array}{l}\text { System incorporating } 40 \% \text { water-based silane, crack-filling caulk } \\
\text { and epoxy flood coat on top surface }\end{array}$ \\
\hline Arkansas (2012) & Concrete pavement & $\square$ & $\begin{array}{l}100 \% \text { silane } \\
40 \% \text { water-based silane }\end{array}$ \\
\hline Delaware (2009) & Concrete pavement & घ & Topical lithium application \\
\hline Maine (2010) & $\begin{array}{l}\text { Bridge abutments, wing } \\
\text { walls and bridge columns }\end{array}$ & $\begin{array}{l}\mathbf{\square} \\
\mathbf{\square} \\
\mathbf{\square} \\
\mathbf{\square}\end{array}$ & $\begin{array}{l}100 \% \text { silane } \\
40 \% \text { water-based silane } \\
\text { Elastomeric coating } \\
\text { Electrochemical lithium treatment } \\
\text { Carbon FRP wrap }\end{array}$ \\
\hline $\begin{array}{l}\text { Massachusetts (2005 } \\
\text { and 2010) }\end{array}$ & Highway barriers & $\begin{array}{l}\mathbf{\square} \\
\mathbf{\square} \\
\mathbf{\square} \\
\mathbf{\square} \\
\mathbf{\square} \\
\mathbf{\square}\end{array}$ & $\begin{array}{l}\text { Topical lithium application } \\
\text { Vacuum impregnation with lithium } \\
40 \% \text { silane in isopropyl alcohol } \\
20 \% \text { silane in isopropyl alcohol } \\
20 \% \text { silane in water } \\
\text { Lithium silicate-based penetrating sealer } \\
\text { Elastomeric coating }\end{array}$ \\
\hline Rhode Island (2012) & $\begin{array}{l}\text { Bridge abutments, retaining } \\
\text { wall and highway barriers }\end{array}$ & $\mathbf{\square}$ & $\begin{array}{l}100 \% \text { silane } \\
40 \% \text { water-based silane } \\
\text { Elastomeric coating }\end{array}$ \\
\hline Texas - Houston (2006) & Bridge columns & $\begin{array}{l}\mathbf{\square} \\
\mathbf{\square} \\
\mathbf{\square} \\
\mathbf{\square}\end{array}$ & $\begin{array}{l}\text { Vacuum impregnation with lithium } \\
\text { Electrochemical lithium treatment } \\
40 \% \text { silane in isopropyl alcohol } \\
\text { Silane-siloxane blend, applied by way of vacuum impregnation } \\
\text { Sodium silicate, applied by way of vacuum impregnation }\end{array}$ \\
\hline $\begin{array}{l}\text { Texas - New Braunfels } \\
(2010)\end{array}$ & $\begin{array}{l}\text { Precast beams (not in service } \\
\text { and with no significant ASR) }\end{array}$ & $\mathbf{\square}$ & $40 \%$ alcohol-based silane \\
\hline Vermont (2010) & Bridge barriers & $\square$ & $\begin{array}{l}100 \% \text { silane } \\
40 \% \text { water-based silane } \\
\text { Alcohol-based silane ( } 40 \% \text { solid; used by local contractor) } \\
\text { Elastomeric coating }\end{array}$ \\
\hline
\end{tabular}

Table 1. Summary of field sites, concrete elements treated and types of treatment under the FHWA ASR Development and Deployment Program

In fact, most barrier walls treated with silanes (water and solvent based, with silane contents from 20 to $40 \%$ ) exhibited a net shrinkage during the course of the 7-year field monitoring programme, as opposed to untreated barriers or barriers treated topically with lithium nitrate that continued to expand during the monitoring period, as illustrated in Figure 5. Although significant expansion reduction has not been noticed yet, the monitoring of bridge barrier walls in Vermont suggests possible reductions in internal relative humidity values and a generally better visual appearance of the barrier walls treated with penetrating sealers and elastomeric coating. Because it has only been about 3 years since selected barrier walls were coated with elastomeric paint (Massachusetts, Vermont and Rhode Island field trials), it is premature to determine its efficacy in reducing relative humidity, ASR-induced expansion, and especially freezing and thawing damage, the latter being the primary motivation for applying this breathable, flexible paint over sections previously treated with silane in Massachusetts.

Lithium nitrate, applied either topically or by vacuum, showed no tangible benefits in terms of reducing expansion or cracking in any of the field trials in which it was applied. This is attributed to the overall lack of penetration of the 


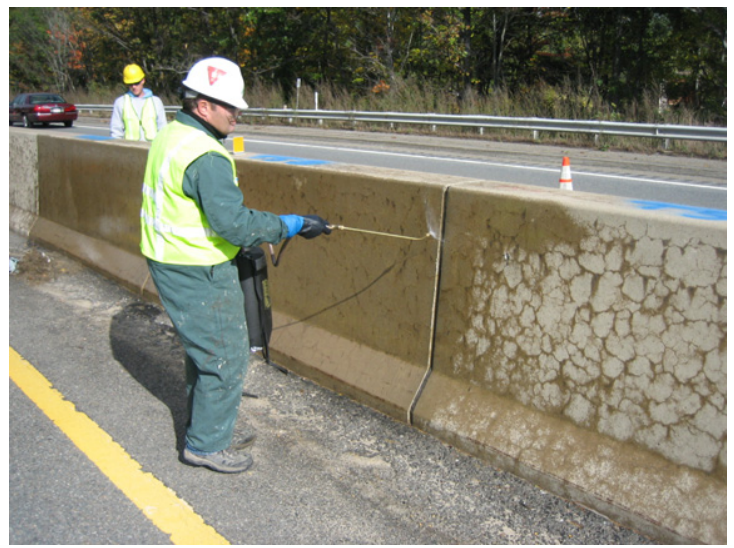

(a)

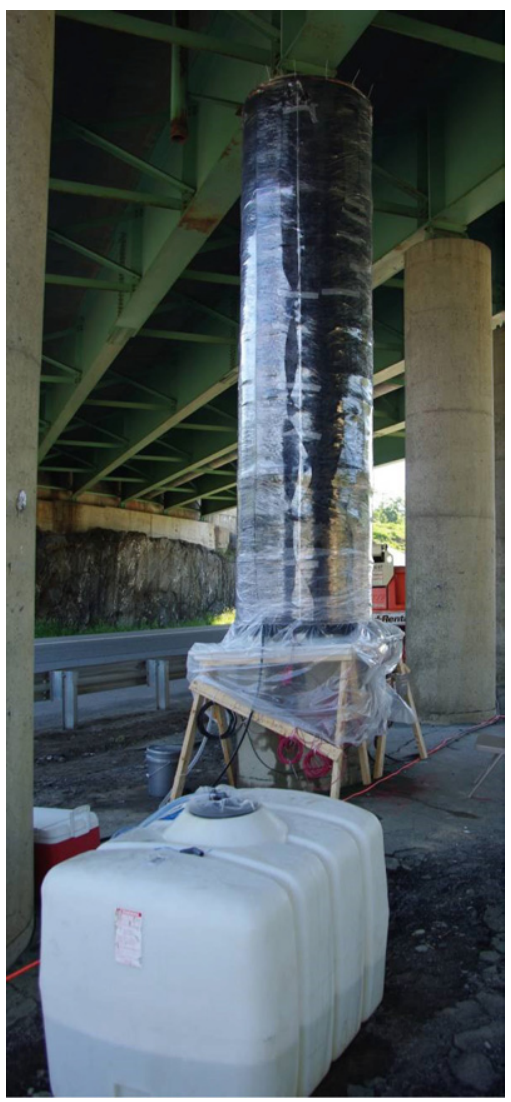

(c)

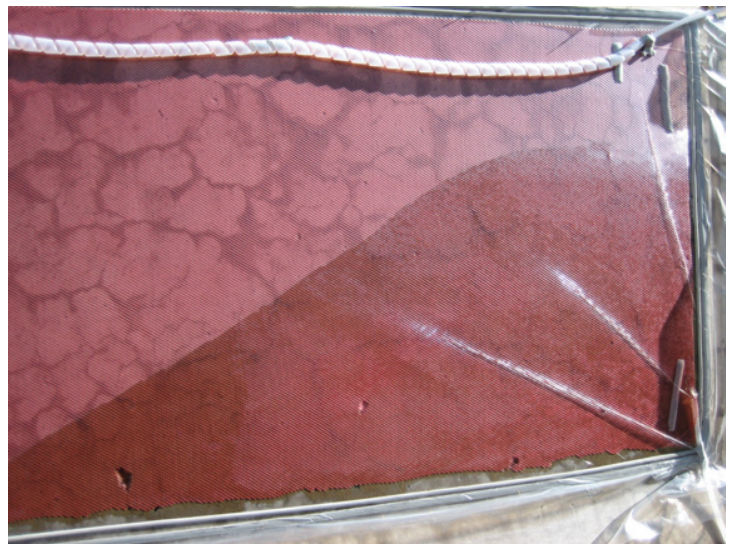

(b)

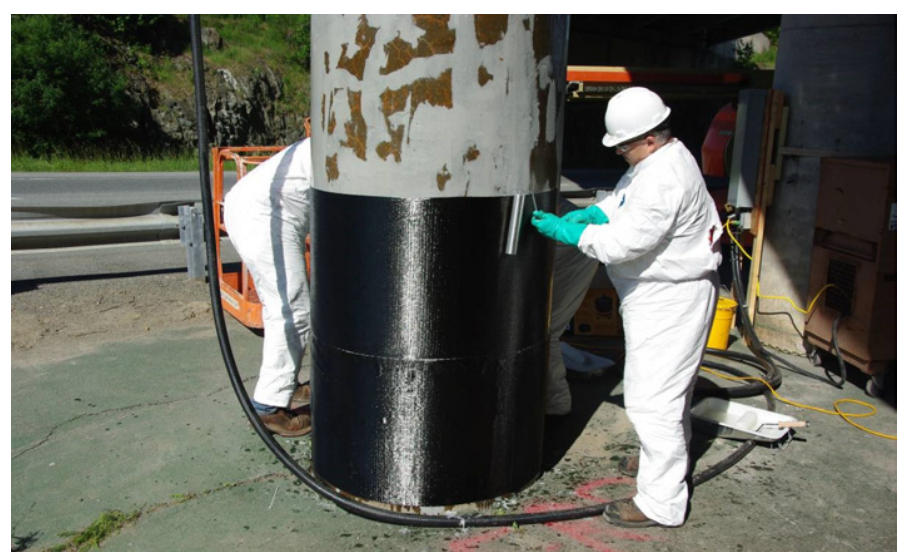

(d)

Figure 2. Mitigation methods/materials: (a) topical application of lithium nitrate, (b) vacuum application of lithium nitrate,

(c) electrochemical application of lithium compounds and

(d) FRP wrap of column

lithium nitrate into the highway barriers. Lithium profiling showed that the depth of lithium penetration into the highway barriers in Massachusetts was minimal, with lithium present only in a concentration above a nominal $100 \mathrm{ppm}$ threshold in the outer $2-4 \mathrm{~mm}(0 \cdot 08-0 \cdot 16$ inch $)$ of barriers that were vacuum impregnated for over $7 \mathrm{~h}$ with lithium nitrate. The penetration was even less for barriers topically treated with lithium. These results are consistent with data obtained 


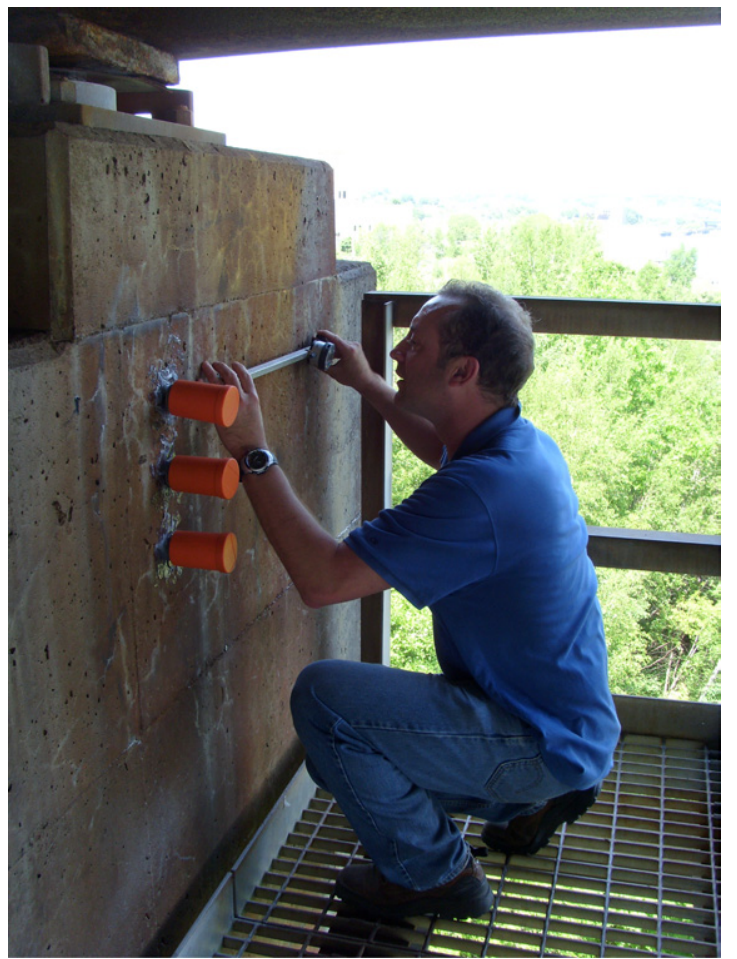

(a)

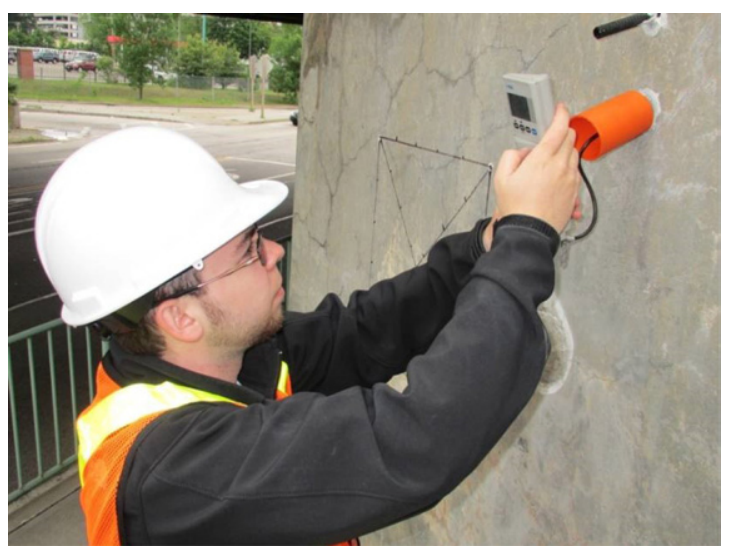

(c)

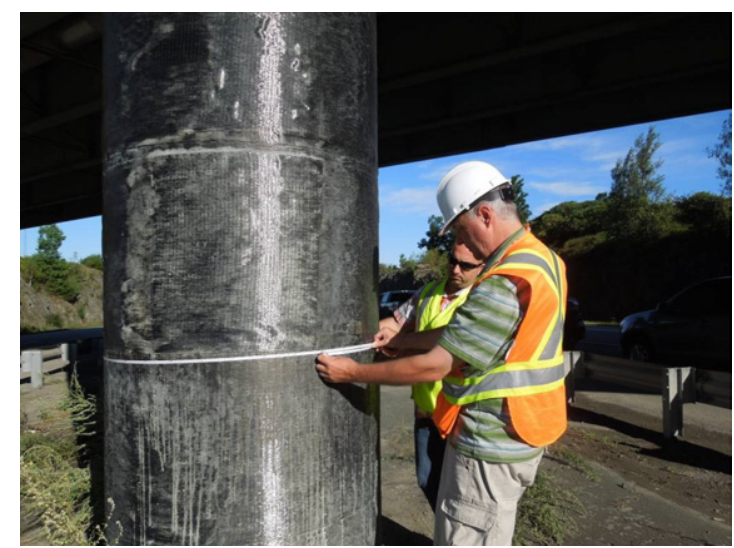

(b)

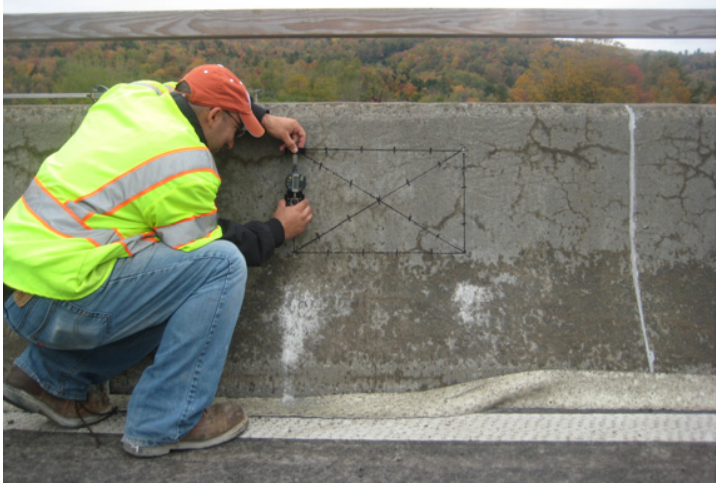

(d)

Figure 3. Examples of monitoring methods, including: (a) linear expansion measurement, (b) circumferential expansion of column wrapped with FRP, (c) internal relative humidity measurement and (d) crack mapping

from the topical applications of lithium to pavements under FHWA field trials in Idaho and Maryland and the topical application of lithium to bridge columns in Houston. Given the lack of lithium penetration, it is not surprising that no beneficial effects of the treatment were observed for any of the pavements or columns treated topically or by vacuum with lithium nitrate.
Electrochemical methods were found to be effective in significantly increasing the depth of lithium penetration when applied to bridge columns in Houston. Lithium was driven all the way to the reinforcing steel (depth of $50 \mathrm{~mm}$ or 2 inch) in a concentration estimated to be sufficient to suppress ASRinduced expansion. However, the migration of other alkali ions (specifically sodium and potassium) leading to increased alkali 


\begin{tabular}{|c|c|c|}
\hline eld sites & & vations \\
\hline Alabama & $\mathbf{\square}$ & $\begin{array}{l}\text { Treatment of ASR-affected arches was 'not' effective } \\
\text { There has been no reduction in relative humidity, and expansion continues unabated }\end{array}$ \\
\hline Arkansas & $\mathbf{\square}$ & Too early to draw conclusions \\
\hline Delaware & - & $\begin{array}{l}\text { No ASR-performance data available } \\
\text { DOT overlaid lithium-treated pavement with asphalt before the impact of the lithium could be } \\
\text { evaluated } \\
\text { Testing of cores indicated very little lithium penetration and it is highly unlikely that the treatment } \\
\text { would have impacted the course of ASR }\end{array}$ \\
\hline Maine & - & $\begin{array}{l}\text { Too early to draw conclusions for abutments and wing walls, but it is possible that moisture supply } \\
\text { from behind the treated elements masks any benefit of silane applied to the surface } \\
\text { The application of a silane to a slender circular column may have reduced expansion, but longer-term } \\
\text { data needed to confirm trend }\end{array}$ \\
\hline Massachusetts & $\begin{array}{l}\square \\
\square \\
\square\end{array}$ & $\begin{array}{l}\text { Silanes appear to have been effective in reducing expansion and reducing the visual symptoms of ASR } \\
\text { ('drying' of cracks) } \\
\text { Lithium treatments (topical or vacuum impregnation) have had no beneficial impact } \\
\text { Elastomeric coating performing well } \\
\text { Longer-term data required to confirm long-term performance }\end{array}$ \\
\hline Rhode Island & घ & Too early to draw conclusions \\
\hline Texas (Houston) & $\mathbf{\square}$ & $\begin{array}{l}\text { The extent of ASR appears to vary significantly between columns tested, making it difficult to } \\
\text { determine the impact of the treatment } \\
\text { There is evidence that silanes have reduced the internal relative humidity to some extent and have } \\
\text { reduced expansion in the long term } \\
\text { Electrochemical lithium treatment appears to have increased expansion. This may be due to a } \\
\text { combination of the significant resaturation that occurs during treatment and the concentration of alkali } \\
\text { hydroxides around the steel (cathode) }\end{array}$ \\
\hline $\begin{array}{r}\text { Texas (New } \\
\text { Braunfels) }\end{array}$ & - & $\begin{array}{l}\text { Based on petrographic evaluation and other microstructural studies, ASR was found not to } \\
\text { be a significant mechanism of distress. The primary mechanism for observed distress has not } \\
\text { been proven, but it is potentially due to excessive volume changes owing to shrinkage (chemical, } \\
\text { autogenous, drying) }\end{array}$ \\
\hline Vermont & $\mathbf{\square}$ & $\begin{array}{l}\text { Too early to draw conclusions } \\
\text { Treatments have improved the visible appearance of the barriers. This is not surprising for the coating } \\
\text { product, but the silanes have reduced the staining associated with the cracks, giving the appearance of } \\
\text { reducing the damage }\end{array}$ \\
\hline
\end{tabular}

Table 2. Field trials: observations based on monitoring through

2012-2013

concentration in the vicinity of the reinforcing steel (used as a cathode during treatment) was also observed (e.g. reinforced concrete columns, Houston field trial). This was accompanied by an increase in hydroxyl ions (and $\mathrm{pH}$ ) as a result of the cathodic reaction, which maintained the electro-neutrality of the concrete pore solution. This phenomenon could potentially exacerbate ASR-induced expansion and cracking in this region. More work is needed to determine if this redistribution of sodium and potassium towards the reinforcing steel has any adverse effects on long-term durability. Although there appears to be a trend of increased expansion (compared with untreated controls) for the columns electrochemically treated with lithium in Houston, more research is needed to determine if this effect is statistically significant.

It is not possible to determine yet the efficacy of silane treatment of concrete that has access to moisture from below or behind, such as pavements or abutment/wing walls. Treatment in Maine, Rhode Island and Arkansas intentionally focused on this very issue, but more time is needed to monitor these sites 


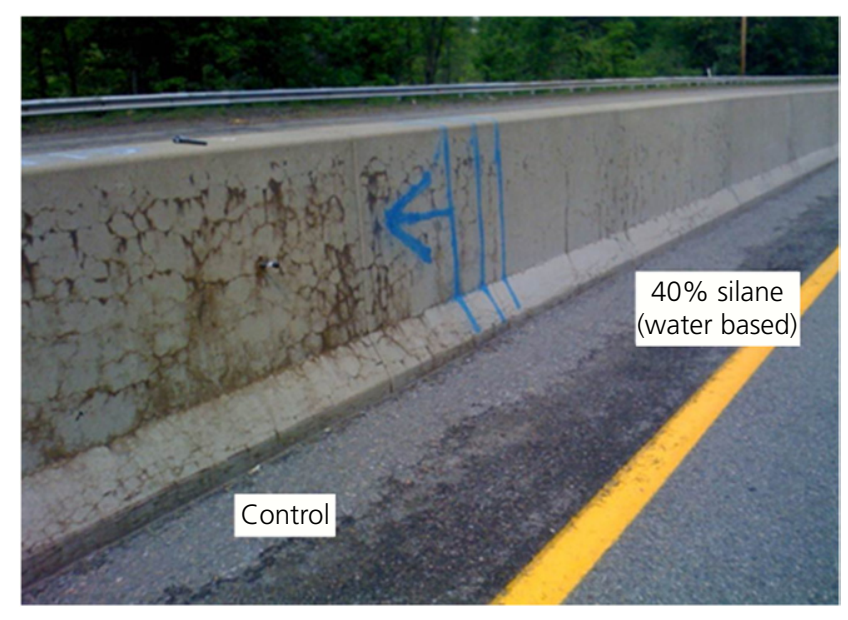

Figure 4. Reduced visual cracking exhibited by barrier walls treated with silane in Massachusetts

to quantify the effects of silane treatment. However, visual survey evaluation confirms that structural elements or sections exposed to external moisture (e.g. rainfall) and sun display more severe deterioration than 'protected' sections (e.g. parts of abutment walls protected under bridge decks). This confirms the key role of 'excess' moisture in the development of extensive cracking/damage due to ASR. There was only one field trial that involved the application of external restraint, in which an ASR-affected circular column was restrained by the application of a FRP wrap, in Maine. Because only limited time has passed since the application of this FRP wrap, it is not yet possible to draw conclusions on its efficacy.

\section{Conclusion}

Alkali-silica reaction has impacted concrete structures throughout the USA, including many cases that have affected transportation infrastructure. This paper provided a brief, interim overview of FHWA-funded field trials aimed at evaluating various methods intended to reduce the future expansion and cracking of ASR-affected pavements, bridges and barrier walls. Owing to the long-term nature of ASR, monitoring over many years is required to quantify accurately the benefits, if any, of the materials and methods aimed at mitigating ASR-induced expansion and cracking. For those field trials that were afforded the longest monitoring period (up to 7 or 8 years), some trends in behaviour became evident - for instance, silanes were found to be particularly effective in reducing internal relative humidity and reducing expansion in highway barriers. On the other hand, the topical or vacuum application of lithium compounds showed no tangible benefits in reducing expansion due to ASR, owing to the inability of the lithium to penetrate into more than the first few millimetres of the treated concrete surface. It is expected that future FHWA efforts will allow for the long-term monitoring of these field trials, thereby providing a more

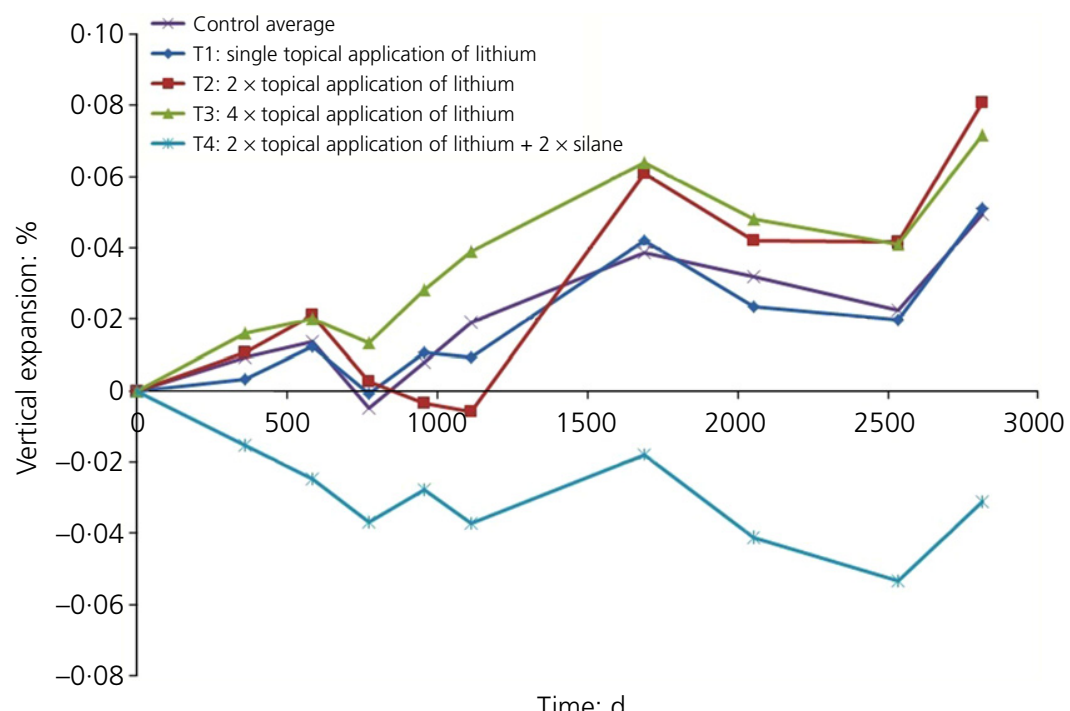

Figure 5. Reduced vertical expansion of barrier walls treated with silane in Massachusetts. Note that the untreated control and barriers treated topically with lithium nitrate (single, double and quadruple application) exhibited continued expansion. The only barriers treated with lithium nitrate that performed well were the ones subsequently treated with silanes. Data from other barriers that were treated with various silane products showed similar reductions in long-term expansion 
accurate assessment of the efficacy of the various mitigation measures.

\section{REFERENCES}

Fournier B, Tremblay S and Frenette J (2009) Results of the Petrographic and Stiffness Damage Testing of Concrete Cores from the Princess Margaret Bridge, Fredericton, NB. Gemtec-Consulting Engineers and Scientists, Canada.

Fournier B, Bérubé MA, Folliard KJ and Thomas MDA (2010) Report on the Diagnosis, Prognosis, and Mitigation of Alkali-Silica Reaction (ASR) in Transportation Structures.
Federal Highway Administration, Washington, DC, USA, Report FHWA-HIF-09-004.

Thomas MDA, Folliard KJ, Fournier B, Rivard B and Drimalas T (2013a) Methods for Evaluating and Treating ASR-Affected Structures: Results of Field Application and Demonstration Projects - Volume I: Summary of Findings and Recommendations. Federal Highway Administration, Washington, DC, USA, FHWA-HIF-14-0002.

Thomas MDA, Folliard KJ, Fournier B et al. (2013b) Methods for Evaluating and Treating ASR-Affected Structures: Results of Field Application and Demonstration Projects Volume II: Details of Field Applications and Analysis. Federal Highway Administration, Washington, DC, USA, FHWA-HIF-14-0003.

\section{WHAT DO YOU THINK?}

To discuss this paper, please email up to 500 words to the editor at journals@ice.org.uk. Your contribution will be forwarded to the author(s) for a reply and, if considered appropriate by the editorial panel, will be published as discussion in a future issue of the journal.

Proceedings journals rely entirely on contributions sent in by civil engineering professionals, academics and students. Papers should be 2000-5000 words long (briefing papers should be 1000-2000 words long), with adequate illustrations and references. You can submit your paper online via www.icevirtuallibrary.com/content/journals, where you will also find detailed author guidelines. 